\title{
Cosmopolitan myodocope ostracods from the Silurian of Uzbekistan, Central Asia
}

\author{
Elena Mikhailova ${ }^{1}$, Vincent Perrier $^{2,3, *}$, Mark Williams ${ }^{3}$, David J. Siveter ${ }^{3}$, Anna Tarasenko ${ }^{1}$, \\ Firuza Salimova ${ }^{4}$ and Irina A. $\mathrm{Kim}^{4}$ \\ ${ }^{1}$ Department of Historical and Dynamic Geology, Saint Petersburg Mining University, Saint Petersburg, Russia \\ ${ }^{2}$ Univ Lyon, Univ Lyon 1, ENSL, CNRS, LGL-TPE, F-69622 Villeurbanne, France \\ 3 School of Geography, Geology and the Environment, University of Leicester, Leicester LE1 7RH, UK \\ ${ }^{4}$ Regional Geological Survey Expedition, Tashkent Region, Uzbekistan
}

Received: 13 November 2019 / Accepted: 21 April 2020

\begin{abstract}
Four species of myodocope ostracod are documented from the Silurian Ludlow Series of the Aburtkan gorge on the southern slope of Dzhalpak Mountain, Uzbekistan: namely, Parabolbozoe bohemica (Barrande, 1872), Bolbozoe anomala Barrande, 1872, Silurocypridina calva Perrier, Vannier and Siveter, 2011 and Richteria migrans (Barrande, 1872). These species have a palaeogeographically widespread transoceanic distribution, which supports the notion that Silurian myodocopes signify the earliest zooplanktonic ostracods. Richteria migrans (Barrande, 1872), in particular, provides a precise intercontinental biostratigraphic marker that identifies rocks of the upper Gorstian to upper Ludfordian stages.
\end{abstract}

Keywords: Ludlow Series / Myodocopa / Ostracoda / palaeobiogeography / plankton / Silurian

Résumé - Les ostracodes myodocopes cosmopolites du silurien Asie centrale. Quatre espèces d'ostracodes myodocopes sont documentées dans le Silurien (Ludlow) des gorges d'Aburtkan sur le versant sud de la montagne Dzhalpak en Ouzbékistan: Parabolbozoe bohemica (Barrande, 1872), Bolbozoe anomala Barrande, 1872, Silurocypridina calva Perrier, Vannier et Siveter, 2011, and Richteria migrans (Barrande, 1872). Ces espèces ont une distribution paléogéographique trans-océanique durant le Silurien. Cette distribution cosmopolite soutient l'idée que les myodocopes siluriens représentent la première faune d'ostracodes zooplanctoniques. Richteria migrans (Barrande, 1872), en particulier, est un marqueur biostratigraphique intercontinental précis qui permet de dater les roches du Gorstien supérieur au Ludfordien supérieur.

Mots clés : Ludlow / Myodocopa / Ostracoda / paléobiogéographie / plancton / Silurien

\section{Introduction}

During the 1980s and 1990s analysis of distributional and facies data of Silurian myodocopes suggested that some species had colonised pelagic niches during that time and therefore represented the earliest known record of zooplanktonic ostracods (Siveter, 1984; Siveter et al., 1987, 1991; Siveter and Vannier, 1990; Vannier and Abe, 1992; see also Perrier et al., 2015). Subsequent studies of Silurian myodocopes have focused on their systematics, habitats, lifestyles, and biostratigraphical and palaeogeographical utility (Perrier

*Corresponding author: vincent.perrier@univ-lyon1.fr et al., 2007, 2011, 2014a-c, 2019a-c; Perrier, 2012; Perrier and Siveter, 2013). These studies are underpinned by the discovery of five exceptionally preserved myodocope ostracod species from the Silurian, in the Herefordshire Lagerstätte, Welsh Borderland, UK, which provides precise data on the soft anatomy of ancient representatives of the group (Siveter et al., 2003, 2007, 2010, 2013, 2015, 2018).

Myodocope ostracods were identified in the Silurian of Uzbekistan as early as 1966, when fieldwork by A.I. Kim and E. Mikhailova yielded material from the Ludlow Series at the village of Kanda in the North Nuratau Ridge. Written records of myodocopes from Uzbekistan are few. Brief mentions occur in the unpublished theses of Mikhailova (1972, 2000), which list three species of Cypridina Milne-Edwards, 1840 from the 


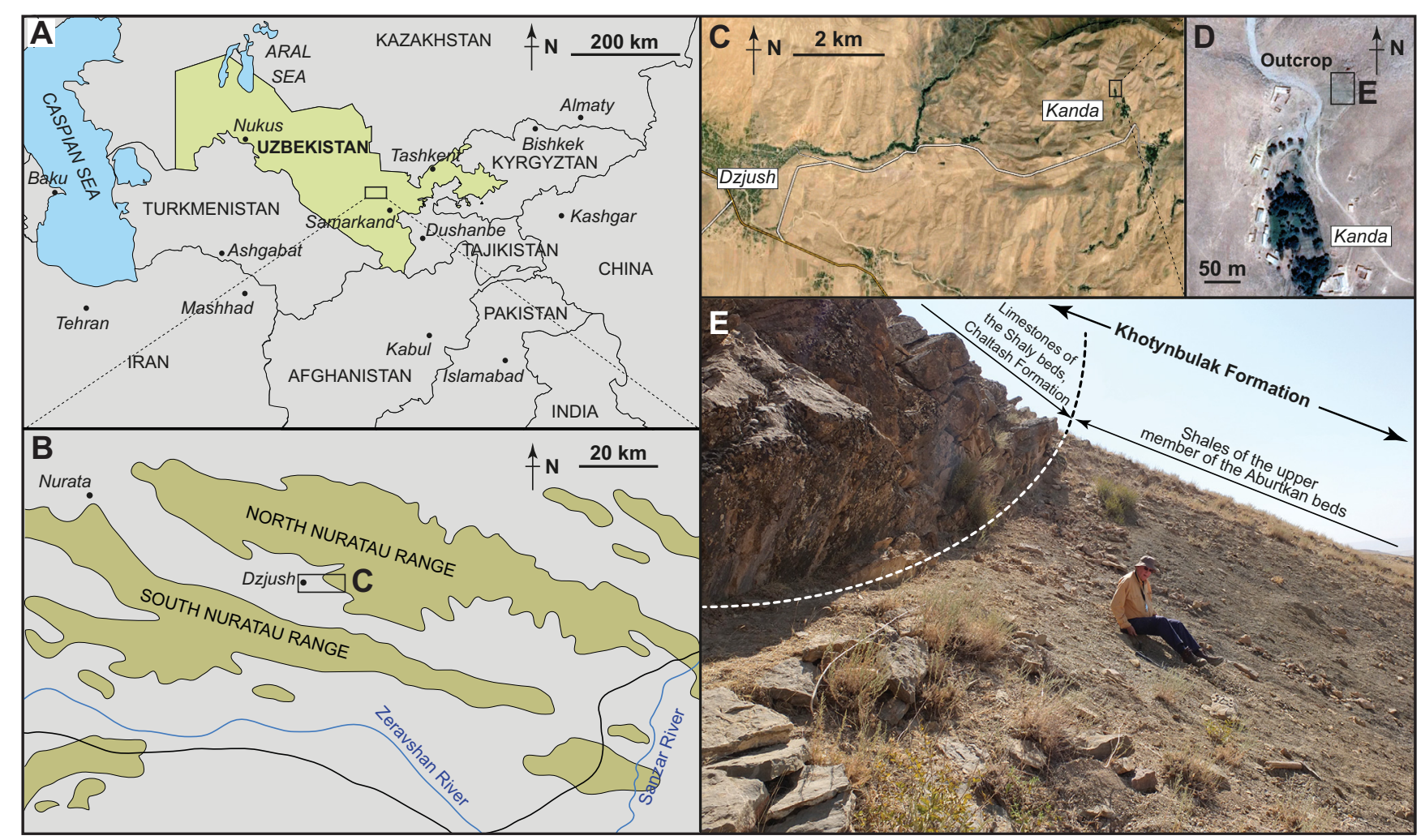

Fig. 1. A-D, Geographical position of the myodocope-bearing Silurian locality of Kanda, Uzbekistan. E, Outcrop of the Ludlow Series near Kanda showing David Siveter at the contact between the shales of the upper member of the Aburtkan beds, Khotynbulak Formation, and the overlying limestones of the Shaly beds, Chaltash Formation.

Pridoli Series of the Kyzyl-Kum Hills of the Tamdy-Tau massif and from the Devonian Lochkovian Stage of the Turkestan Range and Zeravshan Range respectively; species under the names Entomozoe (Richteria) cf. migrans (Barrande, 1872) from the Ludlow of the North Nuratau Ridge and Entomozoe aff. subphalanga subphalanga Polenova, 1970 and Entomozoe aff. tuberosa (Jones, 1861) from the Lochkovian of the Turkestan range; and a new monotypic polycopid genus from the Lochkovian of the Turkestan range. A few myodocope genera (Bolbozoe, Entomozoe and Cypridina) were also listed in Mikhailova's (1981) publication on Pridoli ostracods from the Kyzyl-Kum Hills. Fieldwork undertaken by the present authors in 2014 yielded many additional Silurian myodocope specimens and newly recorded species from the locality at Kanda, and these are the basis of the present paper. Our studies recognise four cosmopolitan myodocope species from the Silurian of Uzbekistan, allowing detailed biostratigraphical correlations with other regions.

\section{Locality and stratigraphy}

The myodocopes were collected from a section outcropping north of the spring at the northern edge of the small hamlet of Kanda, along the side of the Aburtkan gorge on the southern slope of Dzhalpak Mountain. The locality $\left(40^{\circ} 25^{\prime} 40^{\prime \prime} \mathrm{N}\right.$, $66^{\circ} 28^{\prime} 05^{\prime \prime E}$; Fig. 1) lies on the southern slopes of the North Nuratau Ridge and is about $10 \mathrm{~km}$ east of the small town of Dzjush, and some $100 \mathrm{~km}$ north-west of Samarkand. The outcrops in the area of the villages of Kanda, Shaly, ChashmaZrak and others (the Jalpak and Gavalbet mountains) have been known since the middle part of the 20th century but very little has been published on them. The Silurian rock successions are part of the Merishkor synform and collectively are known as the Merishkor sections (Kim, 1966). They consist of richly fossiliferous carbonate and clastic rocks of mostly Silurian Wenlock Series to middle Carboniferous age that have been uplifted and folded during the late Palaeozoic to form part of the southern Tien Shan fold and thrust belt (see, e.g., Biske and Seltmann, 2010; McCann et al., 2013). The myodocopebearing rocks are cyclically arranged calcareous siltstones and mudstones which, following the Uzbek regional stratigraphic scheme, are termed the upper member of the Aburtkan beds of the Khotynbulak Formation. Associates of the myodocopes are orthoconic nautiliods, graptolites, rare small brachiopods and plant fragments; ichnofossils are also present.

These deposits are considered to have accumulated in a low energy, open deep-water shelf/shelf slope setting (Mikhailova and Tarasenko, 2015).

Graptolites from various outcrops and stratigraphic levels of the upper member of the Aburtkan beds comprise Pristiograptus ex gr. dubius, Pristiograptus cf. tumescens, Saetograptus leintwardinensis, Saetograptus chimaera, Colonograptus sp., Monograptus ex gr. haupti, Bohemograptus bohemicus, Bohemograptus bohemicus tenius, Neodiversograptus nilssoni, Linograptus sp. and Lobograptus simplex and Lobograptus progenitor (T.N. Koren of VESEGI, St Petersburg; unpublished list of graptolite taxa sent to Uzbek 
geologist S.Piven, 1984). According to Koren the lower boundary of the upper member of the Aburtkan beds corresponds to the base of the Neodiversograptus nilssoni Biozone and therefore the local base of the Ludlow Series. The precise age of the upper limit of the upper member of the Aburtkan beds is unknown. Based on inter-regional correlation of the myodocope ostracods (see Perrier et al., 2019a, c) that we identify from the locality at Kanda, its Silurian rocks are most likely at the level of the Saetograptus incipiens, Saetograptus leintwardinensis and Monograptus formosus graptolite biozones of the Ludlow Series. The ostracod-bearing strata are succeeded upwards by carbonates of the Shaly beds of the Chaltash Formation, replete with fossils, especially corals, brachiopods, bryozoans, crinoids and podocopid ostracods (Mikhailova, 2000).

\section{Material and methods}

The bivalved carapace of Silurian myodocopes is presumed to have been weakly calcified in life with a probable ligamentous dorsal connection. The myodocopes in our collections occur as internal and external moulds. Due to intense weathering in what is a hot desert area the ostracods are poorly preserved. Among several hundred specimens collected, 71 were firmly identified and are considered in the present paper. Many of the moulds preserve an adductor muscle scar/ spot sub-centrally, corresponding to the site of attachment of the adductor muscle. The surface of the carapace may be smooth or have a range of types of ornament, including reticulation, corrugation and punctation. Some valves show post-mortem diagenetic features, such as "rosettes", similar to features described from Silurian myodocopes of European areas (Siveter et al., 1987).

Rock matrix was removed from the specimens mechanically using fine needles. Casts of external moulds of all of the ostracods recovered were made with silicone rubber (Silcoset 105) using the technique of Siveter (1982). Specimens occurring as internal moulds and casts were coated with a thin layer of ammonium chloride and photographed using a Leitz Aristophot mounted with a Canon EOS 5D camera following the methods of Siveter (1990). Morphological terminology used here follows that of Siveter et al. (1987) and Perrier (2012).

The four central Asian Silurian myodocope species reported on here, are also present in the UK and have been fully revised by Perrier et al. (2019a). Perrier et al. (2019a) presents full synonymies of these four species.

Repositories for the figured ostracods are: Université Claude Bernard Lyon 1, France (FSL), University of Brest, France (LPB), Národní Museum, Prague, Czech Republic (NM-L) and The Polish Academy of Science, Warsaw, Poland (ZPAL). All the newly described and figured material is deposited in Oxford University Museum of Natural History (OUMNH).

\section{Systematic palaeontology}

Class OSTRACODA Latreille, 1802 (nom. correct Latreille, 1806)

Subclass MYODOCOPA Sars, 1866
Order MYODOCOPIDA Sars, 1866

Suborder MYODOCOPINA Sars, 1866

Superfamily BOLBOZOOIDEA sensu BOLBOZOACEA

Bouček, 1936

Family BOLBOZOIDAE Bouček, 1936

Genus Bolbozoe Barrande, 1872

Type species. - Bolbozoe anomala Barrande, 1872; subsequent designation by Bassler and Kellett, 1934. Ludlow Series, Silurian, Prague, Czech Republic.

Other species.-Bolbozoe acuta Perrier et al., 2011, Bolbozoe beccata Perrier et al., 2014c, Bolbozoe largiglobosa Wang and Zhang, 1983, Bolbozoe parvafraga Perrier et al., 2011, Bolbozoe psittaca Perrier et al., 2019a, Bolbozoe rugosa Perrier et al., 2011, Bolbozoe sp. nov. A of Perrier et al., 2019a, Bolbozoe sp. nov. B of Perrier et al., 2019a and possibly Bolbozoe jonesi Barrande, 1872.

Stratigraphic and geographic range.-Upper part of the Wenlock Series, Silurian, to Emsian Stage, Devonian; Czech Republic (Perrier et al., 2011), France (Perrier et al., 2011), Sardinia (Gnoli et al., 2009), China (Wang, 2009), Australia (Perrier et al., 2014c), Wales (Perrier et al., 2019a) and Poland (Perrier et al., 2019b).

Bolbozoe anomala Barrande, 1872 (Figs. 2D, 2H, 2I, 3C, $3 \mathrm{G}, 3 \mathrm{~K}, 3 \mathrm{O}$ and $3 \mathrm{~S}$ )

2019a Bolbozoe anomala Barrande, 1872; Perrier et al.: pl. 3, figs. 1-18 (see p. 26 for full synonymy).

2019b Bolbozoe anomala Barrande, 1872; Perrier et al.: figs. $2 \mathrm{~A}$ and $2 \mathrm{~B}$.

2019c Bolbozoe anomala Barrande, 1872; Perrier et al.: fig. 7C.

Type material. - Lectotype (designated Přibyl, 1988: 119), a right valve, NM-L 23572 (ex. CE1194); Barrande, 1872: pl. 24, figs. 29 and 30; Perrier et al., 2011: pl. 1, fig. 1. Paralectotype (designated Přibyl, 1988: p. 119), a left valve, NM-L 13993; Barrande, 1872: pl. 24, figs. 27 and 28; Perrier et al., 2011: pl. 1, fig. 2.

Type locality. - Lochkov suburb of Prague, Czech Republic.

Type horizon. - Požáry Formation, Pridoli Series, stratigraphical division e2 of Barrande, 1872 (Kříž, 1992).

Material. - Twelve valves from the outcrop at Kanda.

Description.-Adult valve sub-ovoid, slightly tapering posteriorly. Anterior third of valve mostly occupied by a large hemispherical bulb forming c. $20-25 \%$ of valve area; bulbcentre lies just above valve mid-height and well above other surface areas of valve. Maximum valve length is just above bulb mid-height; maximum valve height is at mid-length and maximum valve width is at central part of bulb. A deep, narrow sulcus surrounds the bulb posteriorly and ventrally. An adductor muscle scar occurs at mid-length within the sulcus. Ridges and furrows typical of the muscle scar pattern of the species are not visible in the Uzbek material. In adults, rostrum is very small, in some cases beak-like or absent. Early ontogenetic stages are more rounded in valve outline and the bulb is relatively larger than in adults.

Remarks. - Though the Uzbek material is poorly preserved its features are diagnostic of B. anomala. It differs from other smooth species of Bolbozoe by its rounded shape (B. pisttaca is elongated; Perrier et al., 2019a), its tiny rostrum (B. beccata has a prominent beak-like rostrum; Perrier et al., 2014c) and 




Fig. 2. Lateral views of myodocopes from the upper member of the Aburtkan beds, Khotynbulak Formation, Ludlow Series, of Kanda, North Nuratau Ridge, Uzbekistan. A-C: Richteria migrans: A: left valve (OUMNH CY.00066); B: right valve (OUMNH CY.00067); C: left valve (OUMNH CY.00068). D, H, I: Bolbozoe anomala: D: open carapace in butterfly position (OUMNH CY.00069); H: right valve (OUMNH CY.00070); I: anterior part of right valve showing the bulb and rostrum (OUMNH CY.00071). E-G: Parabolbozoe bohemica: E: anterior part of left valve showing the bulb, rostrum and adductorial muscle scar (OUMNH CY.00072); F: detail of the anteroventral projection of left valve (OUMNH CY.00073); G: left valve showing remnants of the reticulate ornament (OUMNH CY.00074). J, K: Silurocypridina calva: J: anterior part of left valve showing rostrum and the adductorial muscle scar (OUMNH CY.00075); K: open carapace in butterfly position (OUMNH CY.00076). All images are photographs; A-C, E: silicone casts of external moulds; D, F-K: internal moulds. Scale 500 $\mu$ m: specimens A-K.

the lack of a well-developed caudal process (present in $B$. acuta; Perrier et al., 2011, 2019a).

Stratigraphic and geographic range--Ludlow Series, North Nuratau Ridge, Uzbekistan. Also known from the upper part of the Wenlock to at least the middle part of the Pridoli Series. Occurs in the Czech Republic, France, Sardinia (Perrier et al., 2011), Wales and England (Perrier et al., 2019a), and Poland (Perrier et al., 2019b). If B. jonesi is conspecific with $B$. anomala the range of the species would extend into the Lochovian Series, Lower Devonian (see Perrier et al., 2011).

Genus Parabolbozoe Přibyl, 1988

Type species.-Bolbozoe bohemica Barrande, 1872; by monotypy. Ludlow Series, Silurian, Prague, Czech Republic.

Other species. - Parabolbozoe armoricana Perrier et al., 2011 and Parabolbozoe britannica Perrier et al., 2019a.

Stratigraphic and geographic range.-Upper part of the Wenlock to Ludlow or Pridoli Series. Known from the Czech Republic (Perrier et al., 2011), France (Perrier et al., 2011), Sardinia (Gnoli et al., 2009), Wales and England (Perrier et al., 2019a), and Poland (Perrier et al., 2019b).
Parabolbozoe bohemica (Barrande, 1872) (Figs. 2E-2G, $3 \mathrm{~B}, 3 \mathrm{~F}, 3 \mathrm{~J}, 3 \mathrm{~N}$ and $3 \mathrm{R}$ )

2019a Parabolbozoe bohemica (Barrande, 1872); Perrier et al.: pl. 6, figs. 1-13; pl.7, figs. 1-10 (see p. 31 for full synonymy).

2019b Parabolbozoe bohemica (Barrande, 1872); Perrier et al.: figs. $2 \mathrm{D}$ and $2 \mathrm{E}$.

2019c Parabolbozoe bohemica (Barrande, 1872); Perrier et al.: fig. $7 \mathrm{~J}$.

Type material. - Lectotype (designated Bouček, 1936: 63). A left valve, NM-L 23658 (ex. CE1193). Barrande, 1872: pl. 27, fig. 19 (in reverse); Perrier et al., 2011: pl. 3, fig. 1.

Type locality.-Praha-Malá Chuchle, Vyskočilka, Czech Republic.

Type horizon. - Kopanina Formation, Ludlow Series (stratigraphical division e2 of Barrande, 1872; horizon with the trilobite "Cromus" beaumonti).

Material. - Eight valves from the outcrop at Kanda.

Description. - Adult valve is sub-ovoid in lateral outline, gently curved dorsally and ventrally, posteriorly tapering 


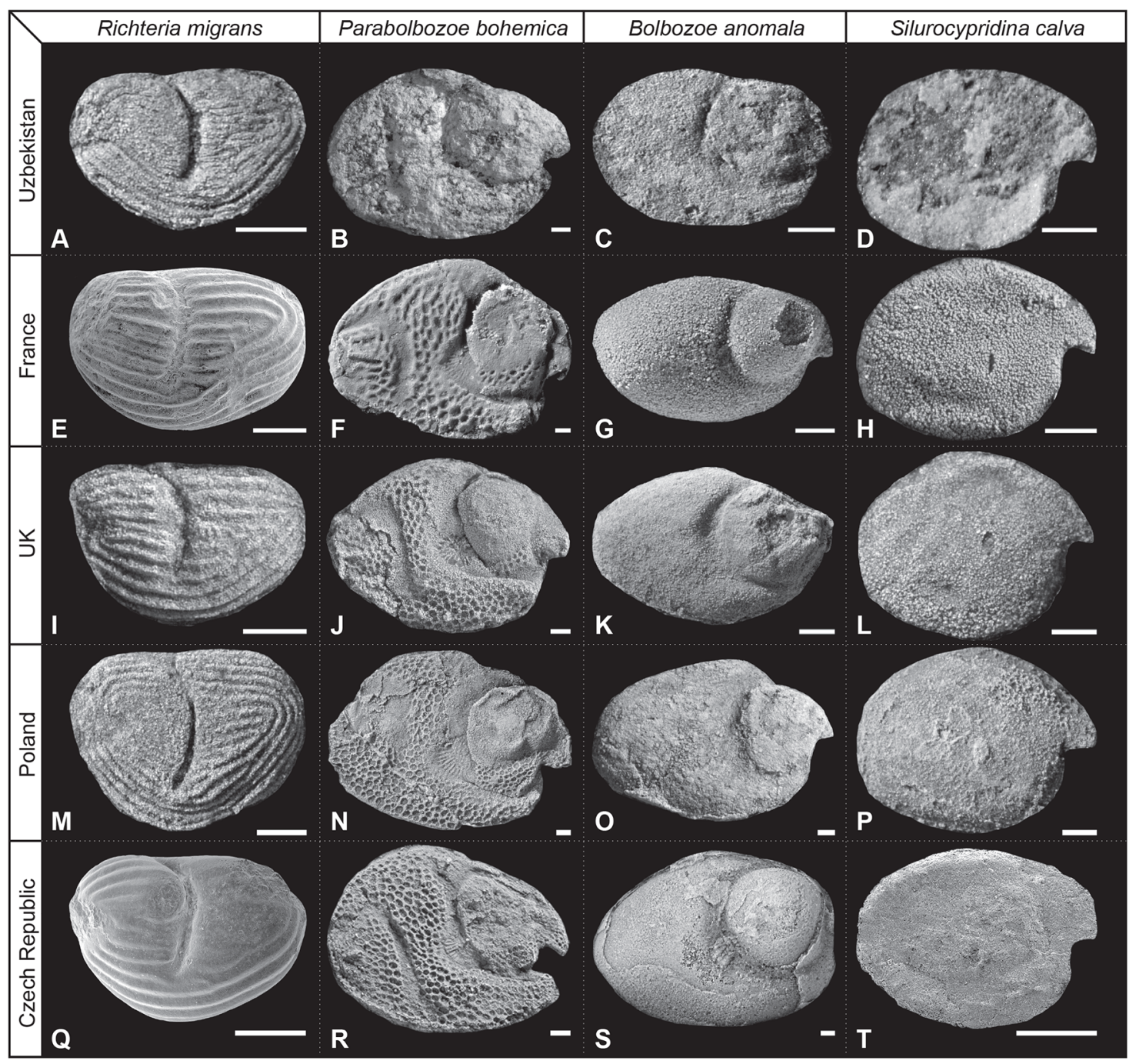

Fig. 3. Lateral views of four species of Silurian myodocopes from the North Nuratau Ridge, Uzbekistan (A-D), France (E-H), the UK (I-L), Poland (M-P) and the Czech Republic (Q-T). A, E, I, M, Q: Richteria migrans: A: left valve (OUMNH CY.00066); E: left valve (FSL 705029a); I: right valve, image reversed (OUMNH 35481); M: left valve (ZPAL O.63/6); Q: left valve (FSL 705002a). B, F, J, N, R: Parabolbozoe bohemica: B: left valve, image reversed (OUMNH CY.00074); F: right valve (FSL 710420); J: left valve, image reversed (OUMNH 35087); N: right valve (ZPAL O.63/5); R: left valve, image reversed (FSL 710759). C, G, K, O, S: Bolbozoe anomala: C: right valve (OUMNH CY.00070); G: right valve (FSL 710595); K: right valve (OUMNH 35467); O: left valve, image reversed (ZPAL O.63/24); S: right valve (NM-L 23572, lectotype). D, H, L, P, T: Silurocypridina calva: D: right valve of a carapace (OUMNH CY.00076); H: left valve, image reversed (FSL 710652); L: right valve (OUMNH 35382); P: right valve (ZPAL O.63/11); T: left valve, image reversed (FSL 710772). All images are photographs except $\mathrm{E}$ and $\mathrm{Q}$ which are SEM images. A, F-N, R, T: silicone casts; B-E, O-Q, S: internal moulds. All scale bars: $500 \mu \mathrm{m}$.

slightly. Bulb is large, anterodorsal, has centre above valve mid-height, extends posteriorly to almost line of maximum valve height and ventrally to below valve mid-height; outline is sub-circular, with a slight indentation opposite the rostrum. Rostrum is large, hook-like, generally with a pointed end. Rostral incisure is well developed, below which the valve has a forward pointing projection. Caudal process is not preserved in the Uzbek material. Maximum valve length is at about the level of end of rostrum; maximum valve height is at about valve mid-length; maximum valve width is at the crest of the bulb. A narrow, fairly deep sulcus flanks the bulb posteriorly and ventrally, is widest dorsally and at its mid-length is the site of the adductor muscle scar. In posterior one-third of valve a narrow S-shaped sulcus skirts around dorsal and anterior base of caudal process and projects forward near valve ventral margin. Adductor muscle scar prominent, consisting subparallel, radiating and alternating ridges and furrows arranged in a double series feather-like pattern. In the Uzbek specimens, faint remains of reticulation covers external valve surface. During ontogeny, size of bulb becomes relatively smaller and valve shape changes from almost circular to ovoid and density of reticulation decreases.

Remarks. - Though poorly preserved the Uzbek specimens show the reticulation characteristic of $P$. bohemica. 
P. armoricana has corrugate ornament (Perrier et al., 2011, 2019a) and P. britannica is corrugated and pitted (see Perrier et al., 2019a).

Stratigraphic and geographic range.-Ludlow Series, North Nuratau Ridge, Uzbekistan. Also known from the upper part of the Wenlock and lower part of the Ludlow Series. Occurs in the Czech Republic, France, Sardinia (Perrier et al., 2011), England and Wales (Perrier et al., 2019a) and Poland (Perrier et al., 2019b).

Suborder ENTOMOZOCOPINA Gründel, 1969

Superfamily ENTOMOZOIDEA sensu ENTOMOZOACEA Přibyl, 1950

\section{Family ENTOMOZOIDAE Přibyl, 1950}

Genus Richteria Jones, 1874

Type species.-Cypridina serrato-striata Sandberger, 1845; subsequent designation by Kegel, 1934: 413. Lower Famennian, Upper Devonian of Germany.

Stratigraphic and geographic range.-Richteria is known from the Silurian and Devonian. Supposed records of its occurrence in younger and older strata (all the unrevised "Entomis" species, see Bassler and Kellett, 1934) lie outside the scope of the present study and have not been confirmed by the present authors. The genus is known from Europe (Czech Republic, Germany, Poland, Belgium, France, Italy, U.K.; Perrier et al., 2007, 2019a-c), Arctic Russia (Perrier et al., 2014a), Central Asia, and China (Perrier et al., 2007).

Richteria migrans (Barrande, 1872) (Figs. 2A-2C, 3A, 3E, $3 \mathrm{I}, 3 \mathrm{M}$ and $3 \mathrm{Q}$ )

1981 Entomozoe; Mikhailova, p. 130, fig. 3.

2019a Richteria migrans (Barrande, 1872); Perrier et al.: pl. 12, figs. 1-3, 11 and 12 (see p. 39 for full synonymy).

2019b Richteria migrans (Barrande, 1872); Perrier et al.: fig. $2 \mathrm{~F}$.

2019c Richteria migrans (Barrande, 1872); Perrier et al.: fig. $7 \mathrm{~L}$.

Type material.-Lectotype (subsequently designated by Přibyl, 1950: 11). An incomplete right valve; Národní Museum, Prague, on slab NM-L 22944. Barrande, 1872: pl. 24, figs. 12-14; Bouček, 1936: text-fig. 2a; Perrier et al., 2007: text-figs. $6 \mathrm{a}-6 \mathrm{~b}$.

Type locality.-Former Dvorce quarry (today Podolí swimming pool), Podolí district of Prague.

Type horizon. - Kopanina Formation, Ludlow Series. Material. - Forty-two valves from Kanda.

Description. - Valve large, bean-shaped in lateral outline. Greatest length is slightly above mid height; greatest height is at the adductorial sulcus. Dorsal margin shorter than valve length. Preadductorial and postadductorial areas very slightly curved dorsally; ventral, anterior and posterior margins convex. Anterior valve margin shows a faint notch in some large specimens. Adductorial sulcus long, deep, crescent shaped, extends two-thirds of valve height from in front of mid length near dorsal margin to below the preadductorial node. A simple elliptical adductor muscle scar is present at the slightly widened ventral extremity of the sulcus. Preadductorial node is generally unornamented but can be weakly ribbed and less developed in some specimens. External valve surface has up to 25 longitudinal ribs, including in some specimens short, intercalated and bifurcated ribs. The alignment of ribs is not disturbed by the adductorial sulcus. Ribs merge posteriorly, converge on a triangular smooth area anteriorly and curve slightly away from the valve margin ventrally. Conjoined open valves are consistently connected along dorsal margin, but there is no evidence for presence of hinge structure.

Remarks.-The specimens of $R$. migrans are the best preserved among the Uzbek myodocopes, notably showing the typical entomozoid ribbed ornament. Morphological comparison with material from other regions (see Figs. 3A, 3E, 3I, 3M and $3 \mathrm{Q}$ ), resolves the specimens recorded as Entomozoe (Richteria) cf. migrans (Barrande, 1872) by Mikhailova (1972, $2000)$ as conspecific with $R$. migrans.

Stratigraphic and geographic range. - Ludlow Series, North Nuratau Ridge, Uzbekistan. Also known from the upper part of the Ludlow Series in the Czech Republic, France, Sardinia, Poland, Central Asia, Arctic Russia, England, Wales and possibly Germany and Sweden (Perrier et al., 2007, 2014a, 2019a-c).

Superfamily CYPRIDINOIDEA sensu CYPRIDINACEA Baird, 1850

Family CYPRIDINIDAE Baird, 1850

Genus Silurocypridina Perrier et al., 2011

Type species.-Silurocypridina retroreticulata Perrier et al., 2011 from the Silurian of France.

Other species. - Silurocypridina variostriata Perrier et al., 2011 and Silurocypridina calva Perrier et al., 2011.

Stratigraphic and geographic range.-Silurian (upper Ludlow or Pridoli Series); France, Czech Republic, England, Wales, Poland and possibly Sardinia (Perrier et al., 2011, 2019a-c).

Silurocypridina calva Perrier et al., 2011 (Figs. 2J, 2K, 3D, $3 \mathrm{H}, 3 \mathrm{~L}, 3 \mathrm{P}$ and $3 \mathrm{~T}$ )

2019a Silurocypridina calva Perrier et al., 2011; Perrier et al.: pl. 17, figs. 1-5 and 8-11 (see p. 49 for full synonymy).

2019b Silurocypridina calva Perrier et al., 2011; Perrier et al.: fig. 2L.

2019c Silurocypridina calva Perrier et al., 2011; Perrier et al.: fig. $7 \mathrm{~T}$.

Type material.-Holotype, a three-dimensionally preserved left valve (LPB 18926). Perrier et al., 2011: pl. 5, figs. 8 and 9.

Type locality. - Les Chevrolières, near St Denis-d'Orques, Sarthe, France.

Type horizon. - Le Val Formation is in the upper part of the Ludlow Series or lower part of the Pridoli Series, and currently cannot be further resolved.

Material. - Nine valves from the outcrop at Kanda.

Description. - Valve dome-like, with sub-ovoid lateral outline; hinge short. Rostrum well developed, is about $10-20 \%$ of valve length, protrudes distinctly forward beyond anteroventral margin of valve. Rostral incisure well developed, rounded to angular in lateral outline. Adductor muscle scar is small, subcentral, crescent-shaped and convex anteriorly. Valves smooth. During ontogeny valve shape changes from almost circular to sub-ovoid.

Remarks. $-S$. calva is known to display considerable variation in valve outline and shape of the rostrum. The morphology of the rostrum, the crescent-shaped muscle scar and 
lack of ornament assign the Uzbek material to $S$. clava. Other species of Silurocypridina are reticulate $(S$. retroreticulata) or corrugate (S. variostriata; Perrier et al., 2011, 2019a).

Stratigraphic and geographic range.-Ludlow Series, North Nuratau Ridge, Uzbekistan. Also known from the Silurian of the Czech Republic, France, Poland, England, Wales and possibly Sardinia (Perrier et al., 2011, 2019a-c).

\section{Discussion}

\subsection{Palaeogeographical position and significance}

Central Asia in general contains a collage of structurally complex terranes whose relationships and geological history are intricate and controversial (McCann et al., 2013; Kröner, 2015). The assignment of the region of Uzbekistan in question to a particular terrane/palaeocontinental area and its palaeogeographic position during the Silurian is very conjectural and has elicited a wide range of opinions. Several studies have treated the area of the North Nuratau Ridge of Uzbekistan as part of an "Alai Terrane Group", whose position during the Silurian is considered problematic but which is generally accepted to have accreted with a "Kazakh" (micro) continent during the Carboniferous. Biske and Seltmann's (2010) tectonic synthesis and palaeogeographic reconstruction of pertinent areas of central Asia during Devonian times placed Kyzulkum-Alai, Merishkor-Ulan and several other "microcontinents" within a "Turkestan Ocean" positioned in subtropical latitudes between the Baltica plate and the Kazakh continent. Heubeck's (2001) reconstruction shows a broadly similar plate configuration. McCann et al.'s (2013) synthesis of the Ordovician-Carboniferous tectono-sedimentary evolution of the North Nuratau region allies its position in the Silurian to a carbonate (-clastic) dominated Alai microcontinent positioned astride the equator in the Turkestan Ocean and opposite the Kazakh continent some 20 degrees to the north.

Interestingly, various Upper Silurian non-myodocope benthic ostracod associations are similar in shelf facies over a large area of Uzbekistan, from the Turkestan-Nuratau mountain region to the Kyzyl-Kum hills (Mikhailova, 1981, 2000 and unpublished analyses). Such occurrences would link the supposed palaeogeographically close Kyzylkum-Alai and Merishkor-Ulan microplates of various authors. Furthermore, such ostracod faunas are compositionally closest to faunas of the western and eastern slopes of the northern and central Urals, as well as the western slope of the southern Urals (Abramova, 1976; Mikhailova, 1981).

Fossils have not yet proved decisive in determining the palaeogeographical positioning of the many central Asian terranes (see Cocks and Torsvik, 2002, 2013; Fortey and Cocks, 2003; Torsvik and Cocks, 2013). On balance of the available evidence we tentatively regard the Uzbek region/ terrane in question as a small microcontinent placed between the North and South China plates (Fig. 4). This position, in all palaeogeographical reconstructions, lies many tens of degrees longitudinally distant from the Baltica, Laurentia and Avalonia palaeocontinents, and in general also accords with the palaeogeographical location of the Alai (-Tarim) terrane as resolved by Yakubchuk (2017), who regards it in close proximity to the North China plate in northerly subtropical latitudes.

\subsection{Biostratigraphical significance}

The biostratigraphic control using graptolites recorded by T.N. Koren (unpublished written information given to Uzbek geologist S. Piven; typed records stored in the Uzbekistan Geological Survey, Tashkent) from various outcrops and stratigraphic levels of the upper member of the Aburtkan beds narrows down the biostratigraphical age of the present Uzbek ostracod material to the nilssoni to formosus graptolite biozones of the Ludlow Series (Fig. 4). Based on interregional correlation of the myodocope ostracods (see Perrier et al., 2019a, c) that we identify from the locality at Kanda, the Silurian rocks there are most likely of the upper Gorstian (scanicus/incipiens Biozone) to upper Ludfordian (leintwardinensis and formosus biozones). One myodocope species, $R$. migrans, is particularly informative as it is restricted to the Ludfordian in the UK, Germany, Gotland, Arctic Russia, France, Sardinia and Bohemia (Perrier et al., 2014a, 2019a, c). However, its presence in the mid-Gorstian scanicus Biozone of Poland (Perrier et al., 2019b) may imply that this species originated earlier. The other three myodocope species found in Kanda are all long-ranging species and thus do not provide additional biostratigraphic control. B. anomala is known from strata of the lower Homerian to the upper Pridoli, P. bohemica from strata of the upper Homerian to the uppermost Ludfordian, and S.calva from the upper Homerian to the upper Pridoli (Perrier et al., 2019a, c; Fig. 4). The coincidence of the four Uzbek myodocope species corresponds to the assemblage present in the $R$. migrans myodocope biozone of the UK (Perrier et al., 2019a, c), coeval to the leintwardinensis graptolite biozone and the Fungochitina pistilliformis? chitinozoan biozone (Steeman et al., 2015; Fig. 4). The Richteria migrans Biozone is also recognized in Germany (Perrier et al., 2014a), Gotland (Perrier et al., 2014a), Arctic Russia (Perrier et al., 2014a), France (Perrier et al., 2007), Sardinia (Perrier et al., 2007) and Bohemia (Perrier et al., 2007).

\subsection{Palaeoecological significance}

The widespread palaeogeographic distribution of $R$. migrans, B. anomala, P. bohemica and S. calva in southerly tropical to mid latitudes on both sides of the early Palaeozoic Rheic Ocean, was noted by Siveter et al. (1991) and Perrier et al. (2007, 2011, 2019a). Perrier et al. (2014a) expanded the distribution of $R$. migrans to the subtropical region of the palaeo-northern hemisphere on, or next to, the Siberia palaeocontinent (Fig. 4). These new Uzbek records at tropical latitude in the palaeo-northern hemisphere, thousands of kilometres east of the previous ones, therefore reinforce the idea that $R$. migrans, B. anomala, $P$. bohemica and $S$. calva had wide dispersal capacities (Fig. 4).

Our new observations also confirm that, as noted by Siveter et al. (1991) and Perrier et al. (2007, 2011, 2019a), the occurrences of bolbozoids, entomozoids and cypridinids are characteristically associated with either dark micritic limestones (e.g., Arctic Russia, Sardinia, Montagne Noire) or shales (e.g., Bohemia, Armorican Massif, Poland, Central Asia). In addition to myodocopes, these lithologies typically contain, inter alia, orthoconic nautiloid, graptolite, phyllocarid 


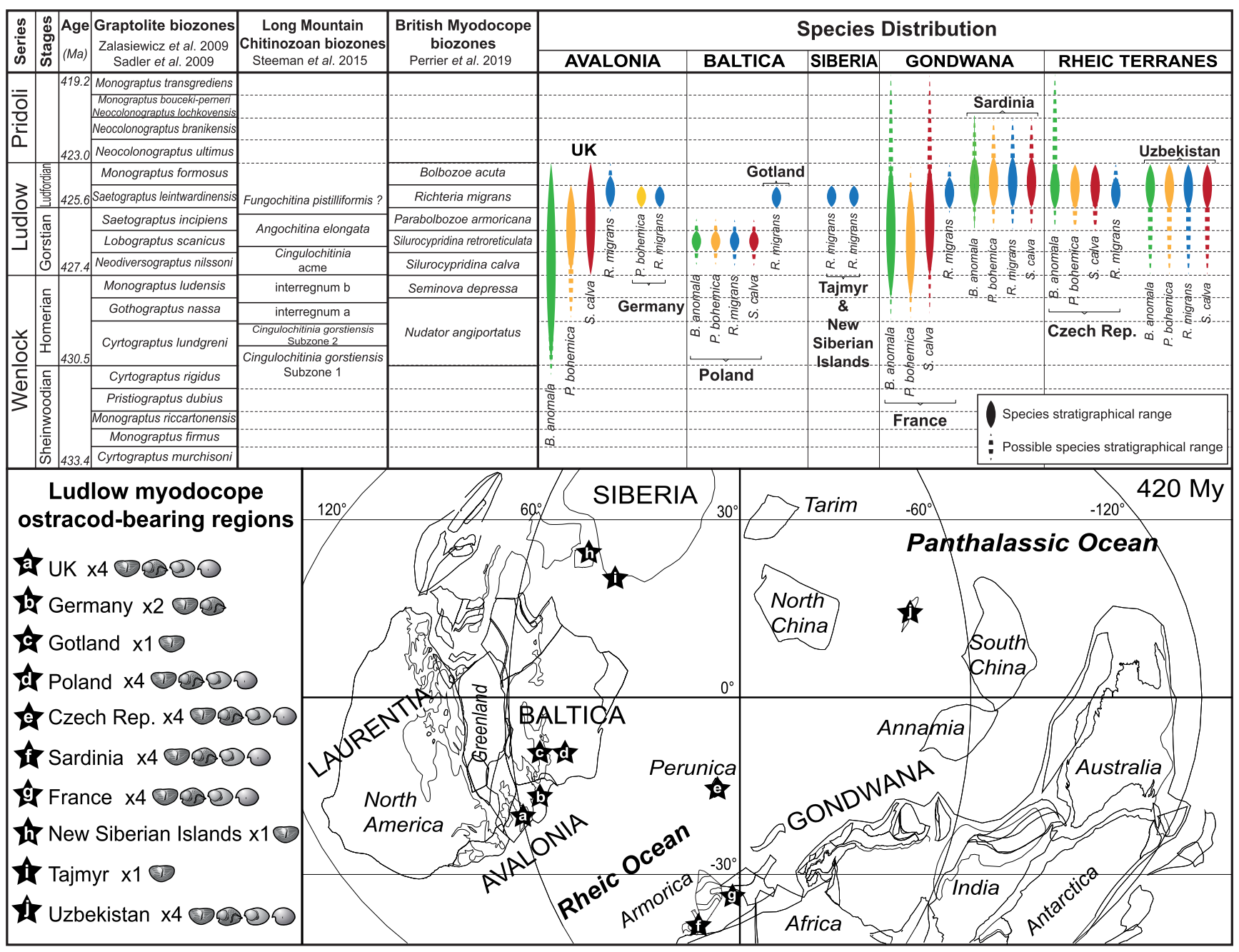

Fig. 4. Stratigraphic and palaeogeographic distribution of selected Silurian myodocope species in Uzbekistan, UK, Germany, Poland, Gotland, Artic Russia, France, Sardinia and the Czech Republic. Map for the Ludlow (420 Ma) after Torsvik and Cocks (2013).

and bivalve dominated associates, as in the case of the occurrence in Uzbekistan. The myodocope-bearing facies typify possible deep shelf environments or topographic lows on the shelf (Siveter et al., 1991; Perrier et al., 2011) and are characterised by the lack of bioturbation, the presence of lamination and by a low diversity mostly pelagic fauna. These facies data, added to the newly extended cosmopolitan distribution suggest that at least these four myodocope species probably possessed a pelagic lifestyle, and this is consistent with the timing of a proposed ecological shift in pioneer pelagic (myodocope) ostracods from benthic to pelagic during the mid-Silurian (see Siveter, 1984; Siveter et al., 1987, 1991; Siveter and Vannier, 1990; Vannier and Abe, 1992; Perrier et al., 2007, 2011, 2015, 2019a, b).

Acknowledgements. We are grateful to the Saint Petersburg Mining University and the Regional Geological Survey Expedition, Tashkent Region, Uzbekistan, for making the fieldwork possible. We also thank the reviewers Dr Marie
Béatrice Forel (MNHN, Paris) and Prof. Alan Lord (Senckenberg Museum, Frankfurt) for their helpful comments on the manuscript. This research was funded by The Leverhulme Trust (grant RPG-324).

\section{References}

Abramova AI. 1976. Ostracody iz verkhnesiluriyskich otlozheniy zapadnogo sklona Yuzhnogo Urals (basseyn Reki Irgizly i M. Ik). (Ostracods from Upper Silurian deposits of the western slope of the Southern Urals: basin of the Irgizly and Little Ik rivers). Biostratigraphy and environment of the Palaeozoic deposits of the Southern Urals and the Eastern Edge of the Russia Platform. BFAN USSR, 41-45 [in Russian].

Baird W. 1850. The Natural History of the British Entomostraca. London: The Ray Society, $364 \mathrm{p}$

Barrande J. 1872. Système Silurien du centre de la Bohème, 1. Prague-Paris, 647 p. 
Bassler RS, Kellett B. 1934. Bibliographic index of Paleozoic Ostracoda. Geological Society of America Special Papers 1: 500.

Biske YS, Seltmann R. 2010. Paleozoc Tian-Shan as a transitional region between the Rheic and Urals-Turkestan oceans. Gondwana Research 17: 602-613.

Bouček B. 1936. Die Ostracoden des böhmischen Ludlows (Stufe eß). Neues Jahrbuch für Mineralogie, Geologie und Paläontologie 76: 31-98.

Cocks LRM, Torsvik TH. 2002. Earth geography from 500 to 400 million years ago: a faunal and palaeomagnetic review. Journal of the Geological Society 159(6): 631-644.

Cocks LRM, Torsvik TH. 2013. The dynamic evolution of the Palaeozoic of eastern Asia. Earth-Science Reviews 117: 40-79.

Fortey RA, Cocks LRM. 2003. Palaeontological evidence bearing on global Ordovician-Silurian continental reconstructions. EarthScience Reviews 61(3-4): 245-307.

Gnoli M, Perrier V, Serventi P. 2009. The state of research on Sardinian Silurian Crustacea. In: Corradini C, Ferretti A, Storch P, eds. The Silurian of Sardinia. Rendiconti della Societa Paleontologica Italiana 3(1): 143-55.

Gründel J. 1969. Neue taxonomische Einheiten der Unterklasse Ostracoda (Crustacea). Neues Jahrbuch für Geologie und Paläontologie 6: 353-61.

Heubeck C. 2001. Assembly of central Asia during the middle and late Paleozoic. Memoirs of the Geological Society of America, 1-22.

Jones TR. 1861. Entomis. In: Howel HH, Geikie A, eds. The geology of the neighbourhood of Edinburgh. Memoirs of the Geological Survey of Great Britain 32: 137.

Jones TR. 1874. Uber Entomis und ein neues Genus Richteria. Neues Jahrbuch für Mineralogie Geologie und Paläontologie (2): 180. [in form of a letter to Prof. Geinitz; title given in the table of contents].

Kegel W. 1934. Zur Kenntnis paläozoischer Ostracoden 4. Über die Gattung Entomis und ihre mittel-devonischen Arten. Jahrbuch der preußischen geologischen Landesanstalt zu Berlin for 1933 54: 409-20.

Kim AI, ed. 1966. Putevoditel' ekskursiy po tipovym razrezam Ordovika, Silura i Devona Sredney Azii. (Guidebook of field excursions to the standard sections of the Ordovician, Silurian and Devonian of Central Asia). MG UzSSR. Tashkent, 112 p [in Russian].

Kř́žž J. 1992. Silurian Field Excursions: Prague basin (Barrandian), Bohemia. National Museum of Wales Geological series, 13. Cardiff, $111 \mathrm{p}$.

Kröner A, ed. 2015. The central Asian Orogenic Belt-Geology, Evolution, Tectonics and Models. Contributions to the Regional Geology of the World, 32, 313 p. Stuttgart, Germany: E. Schweizerbart.

Latreille PA. 1802. Histoire naturelle générale et particulière des Crustacés et des Insectes, Familles naturelles des genres, 3rd ed. Paris : Dupuis, $467 \mathrm{p}$.

Latreille PA. 1806. Genera crustaceorum et insectorum, 1. Paris \& Strasbourg: A. Koenig, 303 p.

McCann T, Nurtaev B, Kharin V, Valdivia-Manchego M. 2013. Ordovician-Carboniferous tectono-sedimentary evolution of the North Nuratau region, Uzbekistan (Westernmost Tien Shan). Tectonophysics 590: 196-213.

Mikhailova ED. 1972. Ostracody silura sapada Yuzhnogo Tjan'Shanja i ikh stratigraficheskoe znachenie (Ostracods of the Silurian of the west of the South Tian'-Shan' and their stratigraphic significance). Leningrad, 213 p. Unpublished thesis; Leningrad Mining Institute [in Russian].

Mikhailova ED. 1981. Rasprostranenie ostrakod v przhidoli Juzhnogo Tjan'-Shanja (Distribution of ostracodes in Pridoli of the Southern Tien Shan). Ezhegodnik VPO, XXIV: 127-142 [in Russian].
Mikhailova ED. 2000. Ostracody silura i nizhnego devona Yuzhnogo Tjan'-Shanja: biostratigraficheskoe znachenie, tafonomija, ekologo-fatsyal'nye soobshcestva. (Ostracods of the Silurian and Lower Devonian of the Southern Tjen'-Shan': biostratigraphic significance, taphonomy, ecological-facies communities). 1, $307 \mathrm{p}$; 2, $95 \mathrm{p}$. Unpublished Thesis; St Petersburg Mining Institute (Technical University) [in Russian].

Mikhailova ED, Tarasenko AB. 2015. Lithological and genetic features and associations of ostracods (crustaceans) of the Khatynbulak, Kurbulak and Chaltash Silurian Formations in the Merishkor synform (Uzbekistan) (theses). In: Materials of the IV International Scientific and Practical Conference of Young Scientists and Specialists in Memory of Academician $A P$, Saint Petersburg, Karpinsky, VSEGEI, pp.60-65 [in Russian].

Milne-Edwards H. 1840. Histoire naturelle des crustacés : comprenant l'anatomie, la physiologie et la classification de ces animaux (Vol. 3). Librairie encyclopédique de Roret.

Perrier V. 2012. An atypical Silurian myodocope ostracod from the Armorican Massif, France. Acta Palaeontologica Polonica 57: 363-73.

Perrier V, Siveter DJ. 2013. The use of "European" ostracode faunas in testing Silurian stratigraphy and palaeogeography. In: Harper DAT, Servais T. eds. Early Palaeozoic Biogeography and Palaeogeography. Geological Society, London, Memoirs, 38, pp. 347-56.

Perrier V, Vannier J, Siveter DJ. 2007. The Silurian pelagic myodocope ostracod Richteria migrans. Transactions of the Royal Society of Edinburgh, Earth Sciences 98: 151-63.

Perrier V, Vannier J, Siveter DJ. 2011. Silurian bolbozoids and cypridinids (Myodocopa) from Europe: Pioneer pelagic ostracods. Palaeontology 54: 1361-91.

Perrier V, Bogolepova OK, Gubanov AP, Siveter DJ, Williams M. 2014a. A pelagic myodocopid ostracod from the Silurian of Arctic Russia. Journal of Micropalaeontology 34(1): 51-57.

Perrier V, Siveter DJ, Williams M, Lane PD. 2014b. An Early Silurian "Herefordshire" myodocope ostracod from Greenland and its palaeoecological and palaeobiogeographical significance. Geological Magazine 151: 591-9.

Perrier V, Siveter DJ, Williams M, et al. 2014c. Myodocope ostracods from the Silurian of Australia. Journal of Systematic Palaeontology 13(9): 727-739.

Perrier V, Williams M, Siveter DJ. 2015. The fossil record and palaeoenvironmental significance of marine arthropod zooplankton. Earth-Science Reviews 146: 146-62.

Perrier V, Siveter DJ, Williams M, Palmer D. 2019a. British Silurian Myodocope Ostracods. Monograph of the Palaeontographical Society, London 172(651): 1-99.

Perrier V, Olempska E, Siveter DJ, Williams M, Legiot N. $2019 \mathrm{~b}$. Silurian myodocope ostracods from Poland. Acta Palaeontologica Polonica 64(2): 379-397.

Perrier V, Williams M, Siveter DJ, et al. 2019c. A high-precision global biostratigraphy of myodocope ostracods for the Silurian upper Wenlock Series and Ludlow Series. Lethaia, https://doi.org/ 10.1111/let.12357.

Polenova EN. 1970. Late Silurian and early Devonian ostracods of the Altai-Sayan region. Trudy Instituta Geologii Geofiziki, Sibirskoe Otdelenie Akademii Nauk SSSR 127: 1-104.

Prribyl A. 1950. On the Bohemian Ostracoda of the families Entomozoidae and Entomoconchidae. Bulletin international de l'Académie tchèque des Sciences 1949: 1-27.

Prribyl A. 1988. Ostracodes from the Silurian of central Bohemia. Sbornik geologicky vĕd Paleontologie 29: 49-143. 
Sadler PM, Cooper RA, Melchin M. 2009. High-resolution, early Paleozoic (Ordovician-Silurian) time scales. Geological Society of America Bulletin 121(5-6): 887-906.

Sandberger G. 1845. Die erste Epoche der Entwickelungsgeschichte der Erdkörpers. Jahrbücher des Vereins für Naturkunde im Herzogthum Nassau 2: 89-124.

Sars, GO. 1866. Oversigt af Norges marine Ostracoder. Norske Videnskcaps-Akademien Forhandlingar 1865: 130.

Siveter DJ. 1982. Casts illustrating fine ornament of a Silurian ostracod. In: Bate RH, Robinson E, Sheppard LM, eds. Fossil and Recent Ostracods. British Micropalaeontological Society. Chichester: Ellis Horwood, pp. 105-22.

Siveter DJ. 1984. Habitats and modes of life of Silurian ostracods. In: Bassett MG, Lawson JD, eds. The Autecology of Silurian Organisms. Special Papers in Palaeontology 32: 71-85.

Siveter DJ. 1990. Photography. In: Briggs DEG, Crowther PR, eds. Palaeobiology: A synthesis. Oxford: Blackwell, pp. 505-8.

Siveter DJ, Vannier J. 1990. The Silurian myodocope Entomozoe from the Pentland Hills, Scotland: its taxonomic, ecological and phylogenetic significance and the affinity of bolbozoid Myodocopes. Transactions of the Royal Society of Edinburgh, Earth Sciences 81: 71-6.

Siveter DJ, Vannier J, Palmer D. 1987. Silurian myodocopid ostracodes: their depositional environment and the origin of their shell microstructures. Palaeontology 30: 783-813.

Siveter DJ, Vannier J, Palmer D. 1991. Silurian myodocopes: pioneer pelagic ostracods and the chronology of an ecological shift. Journal of Micropalaeontology 10: 157-73.

Siveter DJ, Sutton MD, Briggs DEG, Siveter DJ. 2003. An Ostracode crustacean with soft-parts from the Lower Silurian. Science 302: 1749-51.

Siveter DJ, Siveter DJ, Sutton MD, Briggs DEG. 2007. Brood care in a Silurian ostracod. Proceedings of the Royal Society of London, Series B 274: 465-9.

Siveter DJ, Briggs DEG, Siveter DJ, Sutton MD. 2010. An exceptionally preserved myodocopid ostracod from the Silurian of Herefordshire, UK. Proceedings of the Royal Society of London, Series B 277: 1539-44.

Siveter DJ, Briggs DEG, Siveter DJ, Sutton MD, Joomun SC. 2013. A Silurian myodocope with preserved soft-parts: cautioning the interpretation of the shell-based ostracod record. Proceedings of the Royal Society of London, Series B 280(1752): 20122664.

Siveter DJ, Briggs DEG, Siveter DJ, Sutton MD. 2015. A 425million-year-old Silurian pentastomid parasitic on ostracods. Current Biology 25: 1632-1637.

Siveter DJ, Briggs DEG, Siveter DJ, Sutton MD. 2018. A wellpreserved respiratory system in a Silurian ostracod. Biology letters 14(11): 20180464.

Steeman T, Verniers J, Vandenbroucke TRA, Williams M, Perrier V, Siveter DJ. 2015. Stratigraphy and palynology of the Silurian of the Long Mountain (Wales). Geological Magazine 153(1): 95-109.

Torsvik TH, Cocks LRM. 2013. New global palaeogeographical reconstructions for the early Palaeozoic and their generation. In: Harper DAT, Servais T, eds. Early Palaeozoic Biogeography and Palaeogeography. Geological Society, London, Memoirs, 38, pp. 5-24.

Vannier J, Abe K. 1992. Recent and early Palaeozoic myodocope ostracodes: functional morphology, phylogeny, distribution and lifestyles. Palaeontology 3: 485-517.

Wang S-Q. 2009. Palaeozoic Entomozoacea and Leperditicopida (Ostracoda) of China. Fossil Ostracoda of China 3: 251 [In Chinese, English summary].

Wang S-Q, Zhang X-B. 1983. Ostracodes from Lower and Middle Devonian of the Luofu and other areas, Guangxi Province. Acta Palaeontologica Sinica 22: 551-565 [in Chinese, with English summary].

Yakubchuk A. 2017. Evolution of the Central Asian Orogenic Supercollage since late Neoproterozoic revised again. Gondwana Research 47: 372-398.

Zalasiewicz JA, Taylor L, Rushton AWA, Loydell DK, Rickards RB, Williams M. 2009. Graptolites in British stratigraphy. Geological Magazine 146: 785-850.

Cite this article as: Mikhailova E, Perrier V, Williams M, Siveter DJ, Tarasenko A, Salimova F, Kim IA. 2020. Cosmopolitan myodocope ostracods from the Silurian of Uzbekistan, Central Asia, BSGF - Earth Sciences Bulletin 191: 32. 